\title{
HUBUNGAN FAKTOR KUALITAS PRODUK, KUALITAS PELAYANAN, LOKASI DAN LINGKUNGAN DENGAN KEPUTUSAN PEMBELIAN MINUMAN KOPI DI PONDOK KOPI UMBUL SIDOMUKTI
}

\author{
THE RELATIONSHIP FACTORS OF PRODUCT QUALITY, QUALITY OF SERVICE, \\ LOCATION AND ENVIRONMENT WITH DECISIONS FOR PURCHASE OF COFFEE \\ DRINKING IN PONDOK COFFEE UMBUL SIDOMUKTI
}

\author{
OBY ANDREAN*, LASMONO TRISUNARYANTO \\ Fakultas Pertanian dan Bisnis, Universitas Kristen Satya Wacana \\ *E-mail: obyhyunseung0314@gmail.com
}

\begin{abstract}
ABSTRAK
Pondok Kopi Umbul Sidomukti merupakan sebuah kedai yang menyediakan minuman kopi yang terletak di Desa Sidomukti Kecamatan Bandungan Semarang Jawa Tengah, selain itu juga sebagai tempat wisata yang berkonsep agrowisata. Tujuan utama dari penelitian ini adalah: untuk mengetahui hubungan antara faktor kualitas produk, kualitas pelayanan, lokasi dan lingkungan dengan keputusan pembelian minuman kopi di pondok kopi umbul sidomukti. Jenis Penelitian yang digunakan adalah penelitian deskriptif kuantitatif. Jenis data yang digunakan dalam penelitian ini adalah data primer dan data sekunder. Data primer diperoleh dengan menggunakan metode survei dengan wawancara melalui panduan kuesioner dan data sekunder digunakan sebagai penguat data primer, diperoleh dari pihak Pondok Kopi Sidomukti instansi atau lembaga yang terkait. Analisis yang digunakan dalam penelitian ini adalah analisis korelasi rank spearman, dengan jumlah sampel penelitian sebanyak 50 responden yang diambil menggunakan metode accidental sampling. Hasil dari penelitian ini menunjukkan: kualitas produk, kualitas pelayanan, lokasi dan lingkungan, memiliki hubungan yang signifikan serta memiliki tingkat hubungan sedang hingga kuat dengan keputusan pembelian minuman kopi di pondok kopi umbul sidomukti.
\end{abstract}

Kata Kunci: Keputusan Pembelian(1), Perilaku Konsumen(2), Minuman Kopi(3), Pondok Kopi Umbul Sidomukti(4)

\begin{abstract}
Coffee hutsis a coffee shop that provides coffee drinks located in Sidomukti village, Bandungan, Semarang, Central Java agro-tourism concept. The main purpose of this study is: to determine the relationship between product quality factors, service quality, location and environment with the decision to purchase coffee drinks at Sidomukti Umbul Coffee Cottage. This type of research is a quantitative descriptive study. The type of data used in this study are primary data and secondary data. Primary data were obtained using a survey method with interview guideskuesioner and secondary data is used as a reinforcement of the primary data, obtained from the Pondok Kopi Sidomukti institution or institutions concerned. The analysis used in this study was Spearman rank correlation analysis, with a total sample of 50 respondents taken using the accidental sampling method. The results of this study indicate: product quality, service quality, location and environment, have a significant relationship and have a moderate to strong relationship with the decision to purchase coffee drinks at Sidomukti Umbul Coffee Cottage.
\end{abstract}

Kewords: Purchasing Decisions(1), Consumer Behavior(2), Coffee Drinks(3), Sidomukti Umbul Coffee Huts(4) 


\section{PENDAHULUAN}

Kopi merupakan komoditas disektor pertanian dan perkebunan yang banyak dibudidayakan. Kopi juga memiliki nilai ekonomis yang cukup tinggi yang turut menjadi penambah devisa bagi Negara, selain dari sektor minyak dan gas alam. Selain sebagai penyumbang devisa bagi Negara, kopi juga berperan untuk pertumbuhan ekonomi suatu Negara. Terbukti tidak kurang dari setengah juta orang yang penghasilannya dari bekerja di perkebunan maupun penjualan kopi (Marhaenanto, Soedibyo and Farid, 2015). Berdasar hasil proyeksi produksi kopi Indonesia hingga tahun 2023 diperkirakan akan mencapai 777,12 ribu ton kopi berasan.Net ekspor (ekspor-impor) kopi Indonesia tahun 2019-2023 diperkirakan juga akan terus naik, dengan kenaikan ratarata sebesar 0,94\% per tahun. Proyeksi konsumsi/ penggunaan/ ketersediaan untuk konsumsi kopi dalam negeri dari tahun 2019-2023 diperkirakan akan mengalami peningkatan rata-rata sebesar $2,02 \%$ per tahun. Hingga tahun 2023 produksi masih akan terus meningkat dikarenakan luas tanam menghasilkan maupun produktivitas kopi yang terus mengalami peningkatan. Perkembangan produksi kopi tahun 2019 sampai 2023 diperkirakan akan meningkat rata-rata sebesar $1,20 \%$ per tahun, karena perkembangan produktivitas kopi yang terus meningkat dengan rata-rata peningkatan $1,43 \%$ per tahun. Sekitar 94,62\% produksi kopi di Indonesia dipasok dari pengusaha kopi perkebunan rakyat (Pertanian, 2019).

Minuman kopi, merupakan minuman yang berbahan dasar dari hasil ekstrak biji kopi. Minuman kopi dikonsumsi sebanyak 2,25 miliyar gelas setiap harinya diseluruh dunia. Pada tahun 2013, menurut International Coffee Organization kebutuhan kopi dunia di perkirakan sekitar 8,77 juta ton (Kementerian Pertanian, 2016). Wilayah penghasil kopi terbesar di Indonesia yaitu Lampung, Sumatra Utara dan Jawa Timur. Namun wilayah Jawa Tengah juga termasuk wilayah penghasil kopi yang juga terdapat beberapa perusahaan perkebunan kopi. Selain itu di jawa tengbanyak terdapat kedai-kedai yang menyediakan minuman kopi seperti cafecafe dengan produk khusus berbahan dasar kopi untuk minuman.

Seiring dengan meningkatnya permintaan akan kopi di Indonesia yang diiringi perkembangan zaman yang semakin maju, juga diikuti dengan perubahan sikap masyarakat dalam melakukan atau menentukan sebuah pilihan dalam pengambilan keputusan untuk memilih suatu produk. Pada masa ini 
perubahan gaya hidup masyarakat khususnya di perkotaan telah menggeser pola konsumsi masyarakat diantaranya kaum muda yang selalu menginginkan sesuatu yang praktis dan cepat. Dari itu semua pihak penyedia produk juga harus ikut ambil bagian dalam mendukung atau merespon perubahan tersebut. Kaum milenial pada umumnya lebih suka dengan kopi yang bisa langsung dikonsumsi tidak harus menghabiskan banyak waktu. Namun kopi masih menjadi minuman utama pada kalangan usia tua di pedesaan (Kurniawan dan Ridlo, 2017).

Menurut Kotler, P. dan Armstrong, (2008) konsumen sebelum melakukan keputusan pembelian, akan melakukan pembelian terlebih dahulu seperti pengenalan masalah, penggalian informasi dan mencari alternative sebagai alasan lalu kemudian melakukan keputusan pembelian setelah itu akan ada lagi proses pasca pembelian dengan melihat pada tingkat kepuasan konsumen (Ria dan Yuliawati, 2018)

Pondok Kopi Umbul Sidomukti merupakan sebuah cafe yang berada di Desa Sidomukti, Kecamatan Bandungan, Kabupaten Semarang, Jawa Tengah. Lokasi pondok kopi berada di dataran tinggi dengan berbagai panorama yang indah di sekitar café. Pondok Kopi Umbul
Sidomukti berlokasi di tempat pariwisata Umbul Sidomukti Kabupaten Semarang. Dimana juga terdapat hotel dan tempat rekreasi lainnya di sekitar café, yang memungkinkan menjadi tempat destinasi wisata. Pondok kopi umbul sidomukti menyediakan produk kopi dengan beberapa variasi pilihan selain minuman mereka juga menawarkan makanan. Umbul sidomukti sangat cocok untuk menjadi tempat minum kopi karena sesuai karakter lokasi yang berada di ketinggian dengan lingkungan yang sejuk. Karena penjualan produk erat kaitannya dengan keputusan pembelian konsumen dipengaruhi dengan berbagai faktor dalam memutuskan untuk melakukan pembelian yang harus sesuai dengan karakter dan keinginan konsumen. Keputusan pembelian tidak hanya berpedoman pada harga yang murah saja, tetapi juga pada kualitas pelayanan, lokasi usaha, kualitas produk yang ditawarkan, serta lingkungan usaha dan lain sebagainyaaian diatas maka penelitian ini bermaksud untuk mengetahui bagaimanakah hubungan faktor kualitas produk, kualitas pelayanan, lokasi dan lingkungan dengan keputusan pembelian di Pondok Kopi Umbul Sidomukti. 


\section{METODE PENELITIAN}

Tempat pengumpulan data berlokasi di Pondok Kopi Umbul Sidomukti, Desa Sidomukti, Kecamatan Bandungan, Kabupaten Semarang Jawa Tengah. Pemilihan tepmat ditentukan secara sengaja (purposive), karena tempat ini merupakan pusat penjualan minuman kopi. Waktu pelaksanaan pengumpulan data dilakukan pada bulan Februari - Maret 2020 selama kurang lebih satu bulan. Penelitian ini merupakan penelitian deskriptif kuantitatif dengan metode survey. Pengumpulan data dilakukan dengan observasi dan wawancara menggunakan kuesioner. Sumber data yang digunakan adalah data primer dan data sekunder.

Teknik pengambilan sampel menggunakan Accidental sampling terhadap konsumen yang minum kopi di Pondok Kopi Umbul Sidomukti dengan jumlah sampel 50 responden. Pengukuran dilakukan untuk mengetahui hubungan kualitas produk, kualitas pelayanan,lokasi dan lingkungan dengan keputusan pembelian menggunakan data ordinal dengan skala likert dengan pilihan jawaban sangat tidak setuju (STS), tidak setuju (TS), netral (N), setuju (S), dan sangat setuju (SS).
Teknik analisis data yang digunakan untuk melakukan pengolahan data penelitian akan dilakukan dengan menggunakan Software input data dengan Microsoft Exel 2013, SPSS version 16.0 for windows digunakan untuk pengujian instrument data yaitu Uji Validitas, Uji Reabilitas, Uji Korelasi Rank Spearman dan Uji t (Uji Parsial). Untuk melihat tingkat hubungan digunakan tingkat hubungan menurut Sugiyono (2014) yaitu 0,00-0,19 tingkat hubungan sangat rendah, 0,20-0,39 rendah, 0,40-0,59 sedang, 0,600,79 kuat dan 0,80-0,100 sangat kuat. Dan untuk melihat tingkat signifikansi digunakan uji t dengan signifikansi 0,05.

Pengolahan data menggunakan software komputer Microsoft Excel 2013 untuk input data, SPSS versi 16.0 for windows untuk melakukan pengujian instrumen penelitian yaitu uji validitas, uji reliabilitas dan untuk menganalisis data digunakan uji korelasi rank spearman dan uji t. Untuk melihat tingkat hubungan digunakan tingkat hubungan menurut Sugiyono (2014) yaitu 0,00-0,19 tingkat hubungan sangat rendah, 0,20-0,39 rendah, 0,40-0,59 sedang, 0,60-0,79 kuat dan 0,800,100 sangat kuat. Dan untuk melihat tingkat signifikansi digunakan uji t dengan signifikansi 0,05 


\section{HASIL DAN PEMBAHASAN}

\section{Gambaran Umum}

Pada tahun 2007 telah berdiri sebuah kawasan agrowisata umbul sidomukti yang didirikan oleh seorang mantan menteri, Sismono Yudo Husodo, mantan menteri perumahan rakyat tahun 1988-1993 dan di lanjutkan sebagai menteri transmigrasi 1993-1998. Objek wisata ini di resmikan pada tanggal 2 agustus 2007 oleh Bupati Semarang Secara Langsung. Kawasan yang terletak di lereng gunung ungaran ini tepatnya di desa sidomukti, jalan goa jepang, kecamatan bandungan, Semarang, Jawa Tengah. Kawasan ini berada pada ketinggian 1200 di atas permukaan laut dengan luas kawasan 32 hektar. Kawasan agrowisata umbul sidomukti yaitu mengusung konsep wisata alam dengan berbagai macam wahana yang dilengkapi fasilitas wisata yang lengkap. Umbul sidomukti merupakan salah satu objek wisata yang terpavorit yang ada di Semarang. Kawsan agrowisata umbul sidomukti memiliki 6 destinasi wisata yaitu area wisata dengan Taman Renang dan Area Outbond, Pondok Lesehan Ikan Bakar, Pondok Wisata untuk penginapan, Pondok Kopi atau Kedai Kopi untuk bersantai, Villa untuk penginapan dan Resto Panorama semuanya terdapat pada satu kawasan Agrowisata Umbul Sidomukti.

Analisis Karakteristik Responden

Tabel 1 Karakteristik responden berdasarkan usia

\begin{tabular}{ccc}
\hline $\begin{array}{c}\text { Usia } \\
\text { (Tahun) }\end{array}$ & $\begin{array}{c}\text { Jumlah } \\
\text { (Orang) }\end{array}$ & $\begin{array}{c}\text { Persentase } \\
(\%)\end{array}$ \\
\hline $19-26$ & 44 & 88 \\
$27-34$ & 5 & 10 \\
$35-43$ & 1 & 2 \\
\hline Jumlah & 50 & 100 \\
\hline Sumber: Data primer yang diolah 2020
\end{tabular}

Dari tabel 4.1 di atas dapat diketahui bahwa pada rentang usia 19-26 tahun sebanyak 44 orang dengan jumlah persentase $88 \%$. Sedangkan pada rentang usia antara 27-34 sebanyak 5 orang dengan persentase $10 \%$ dan pada rentang usia 3543 tahun sebanyak 1 orang dengan persentase 2\%. Hal ini menunjukkan bahwa responden yang datang untuk membeli minuman kopi di Pondok Kopi Umbul Sidomukti tergolong lebih banyak pada usia mahasiswa sampai dengan memasuki usia kerja.

Pada tabel diatas terlihat yang lebih dominan adalah usia 19-26 tahun dengan jumlah 44 orang sehingga dari usia yang sudah mencapai 19-26 mereka menyukai minuman kopi sambil berlibur atau refreshing menikmati view yang di suguhkan, karena berada pada usia mahasiswa cenderung lebih suka jalanjalan. Sedangkan jika pada usia 27-34 
hanya 5 orang, karena sudah berada pada usia kerja dan mungkin hanya pada harihari libur saja mereka bisa berkunjung untuk minum kopi di pondok kopi umbul sidomukti. Sedangkan pada usia 35-43 hanya 1 orang saja karena pada usia dewasa cenderung lebih memprioritaskan kesehatan untuk lebih banyak beristirahat karena lebih banyak kesibukan dan waktu untuk liburan semakin berkurang.

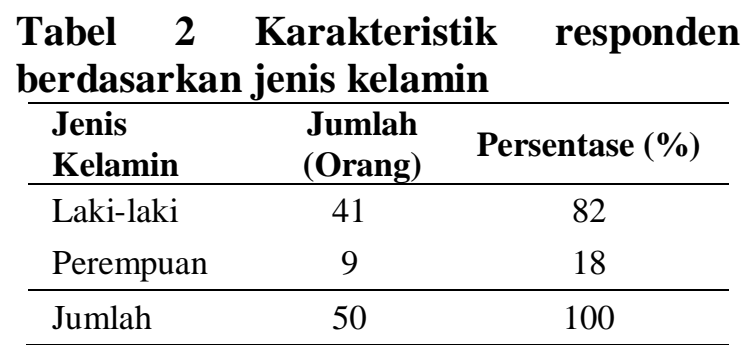

Sumber: Data Primer yang diolah 2020

Dari tabel 2 diatas dapat diketahui bahwa responden yang berjenis kelamin laki-laki sebanyak 41 responden dengan persentase $82 \%$, sedangkan responden yang berjenis kelamin perempuan sebanyak 9 responden dengan persentase $18 \%$.

Pada tabel diatas responden berjenis kelamin laki-laki lebih mendominasi dalam hal membeli minuman kopi di Pondok Kopi Umbul Sidomukti. Sedangkan perempuan hanya menyukai kopi dengan campuran varian rasa selain itu karena pondok kopi umbul juga menyediakan minuman selain minuman kopi diantaranya coklat dan lain-lain.

\begin{tabular}{lcc} 
Tabel & 3 & \multicolumn{2}{c}{ Karakteristik } & Responden \\
Berdasarkan & Tingkat Pendidikan \\
\hline Pendidikan & $\begin{array}{c}\text { Jumlah } \\
\text { (Orang) }\end{array}$ & $\begin{array}{c}\text { Persentase } \\
(\%)\end{array}$ \\
\hline SD & 1 & 2 \\
SMP & 0 & 0 \\
SMA & 8 & 16 \\
Lainya (Sarjana) & 41 & 82 \\
\hline Jumlah & 50 & 100 \\
\hline
\end{tabular}

Sumber: Data Primer yang diolah 2020

Dari tabel 3 dapat dilihat bahwa responden yang paling banyak datang dan membeli minuman kopi di Pondok Kopi Umbul Sidomukti memiliki tingkat pendidikan akhir adalah Lainnya (Sarjana) sebanyak 41 responden dengan persentase $82 \%$. Hal ini dikarenakan sebagian besar responden yang datang dan melakukan pembelian minuman kopi di Pondok Kopi Umbul Sidomukti adalah masyarakat yang berpendidikan akhir Sarjana termasuk yang masih Mahasiswa. Terlihat dari tabel 4.3 diatas bahwa lebih dominan responden memiliki tingkat pendidikan yang sudah memasuki jenjang perguruan tinggi. Dari hal tersebut bisa dilihat bahwa yang membeli minuman kopi di Pondok Kopi Umbul Sidomukti $82 \%$ nya berpendidikan jenjang perguruan tinggi. Karena pondok kopi selain sebagai tempat untuk menikmati kopi juga sebagai tempat wisata yang pasti mengundang minat mahasiswa karena pondok kopi di kelilingi kota-kota Pendidikan. 


\section{Instrument Penelitian}

Tabel 4 Uji Validitas

\begin{tabular}{ccccc}
\hline Variabel Penelitian & Item & $\begin{array}{c}\text { Koefisien } \\
\text { Corelasi }\end{array}$ & r-tabel $(0,05 \%)$ & Keterangan \\
\hline \multirow{5}{*}{ Kualitas Produk $\left(\mathrm{X}_{1}\right)$} & $\mathrm{X}_{1.1}$ & 0,902 & 0,279 & Valid \\
& $\mathrm{X}_{1.2}$ & 0,811 & 0,279 & Valid \\
& $\mathrm{X}_{1.3}$ & 0,829 & 0,279 & Valid \\
& $\mathrm{X}_{1.4}$ & 0,912 & 0,279 & Valid \\
& $\mathrm{X}_{1.5}$ & 0,776 & 0,279 & Valid \\
& $\mathrm{X}_{1.6}$ & 0,707 & 0,279 & Valid \\
\hline & $\mathrm{X}_{2.1}$ & 0,800 & 0,279 & Valid \\
& $\mathrm{X}_{2.2}$ & 0,873 & 0,279 & Valid \\
Kualitas Pelayanan $\left(\mathrm{X}_{2}\right)$ & $\mathrm{X}_{2.3}$ & 0,887 & 0,279 & Valid \\
& $\mathrm{X}_{2.4}$ & 0,740 & 0,279 & Valid \\
& $\mathrm{X}_{2.5}$ & 0,816 & 0,279 & Valid \\
& $\mathrm{X}_{2.6}$ & 0,754 & 0,279 & Valid \\
\hline \multirow{6}{*}{ Lokasi $\left(\mathrm{X}_{3}\right)$} & $\mathrm{X}_{3.1}$ & 0,873 & 0,279 & Valid \\
& $\mathrm{X}_{3.2}$ & 0,775 & 0,279 & Valid \\
& $\mathrm{X}_{3.3}$ & 0,878 & 0,279 & Valid \\
& $\mathrm{X}_{3.4}$ & 0,814 & 0,279 & Valid \\
\hline \multirow{6}{*}{ Lingkungan $\left(\mathrm{X}_{4}\right)$} & $\mathrm{X}_{4.1}$ & 0,933 & 0,279 & Valid \\
& $\mathrm{X}_{4.2}$ & 0,899 & 0,279 & Valid \\
& $\mathrm{X}_{4.3}$ & 0,863 & 0,279 & Valid \\
\hline \multirow{6}{*}{ Keputusan Pembelian } & $\mathrm{X}_{4.4}$ & 0,690 & 0,279 & Valid \\
$(\mathrm{Y})$ & $\mathrm{Y}_{1}$ & 0,759 & 0,279 & Valid \\
& $\mathrm{Y}_{2}$ & 0,748 & 0,279 & Valid \\
& $\mathrm{Y}_{3}$ & 0,823 & 0,279 & Valid \\
& $\mathrm{Y}_{4}$ & 0,782 & 0,279 & Valid \\
& $\mathrm{Y}_{5}$ & 0,848 & 0,279 & Valid \\
& $\mathrm{Y}_{6}$ & 0,707 & 0,279 & Valid \\
\hline & $\mathrm{Y}_{7}$ & 0,794 & 0,279 & \\
\hline
\end{tabular}

Berdasarkan tabel 4 di atas diketahui bahwa hasil dari uji validitas meliputi variabel kualitas produk $\left(\mathrm{X}_{1}\right)$, kualitas pelayanan $\left(\mathrm{X}_{2}\right)$, lokasi $\left(\mathrm{X}_{3}\right)$ dan lingkungan $\left(\mathrm{X}_{4}\right)$ dengan keputusan pembelian (Y) didapat hasil uji validitas nilai keofisien korelasi dari ke-5 variabel lebih besar dari r-tabel. Dengan $\mathrm{n}=50$ pada tingkat kepercayaan 95\%, r-tabel $=2,79$.

Menurut sugiyono, 2014 jika rhitung lebih besar dari r-tabel maka kuesioner valid dari hasil tersebut menunjukan bahwa semua indikator variabel tersebut r-hitungnya lebih besar dari r-tabel maka dapat disimpulkan kuesioner sudah valid. Hal ini berarti indikator yang digunakan mampu mengukur apa yang seharusnya diukur pada setiap variabel atau bisa dilanjutkan untuk pengujian pada tahap selanjutnya. 
Tabel 5 Uji Reliabilitas

\begin{tabular}{lll}
\hline Variabel Penelitian & Cronbach Alpha & Keterangan \\
\hline Kualitas Produk $\left(\mathrm{X}_{1}\right)$ & 0,921 & Reliabel \\
Kualitas Pelayanan $\left(\mathrm{X}_{2}\right)$ & 0,910 & Reliabel \\
Lokasi $\left(\mathrm{X}_{3}\right)$ & 0,891 & Reliabel \\
Lingkungan $\left(\mathrm{X}_{4}\right)$ & 0,887 & Reliabel \\
Keputusan Pembelian $(\mathrm{Y})$ & 0,902 & Reliabel
\end{tabular}

Sumber: Data Primer, 2020

Berdasarkan tabel 4.5 diperoleh hasil dari uji reliabilitas bahwa semua indikator memenuhi kriteria reliabel. Hal ini ditunjukkan oleh nilai cronbach alpha secara keseluruhan indikator dari 5 variabel mendapat nilai $>0,6$ berarti alat ukur (kuesioner) yang dipakai dipercaya atau reliabel.

Tabel 6 Frekuensi jawaban variabel keputusan pembelian

\begin{tabular}{|c|c|c|c|c|c|c|c|c|c|c|c|c|c|}
\hline \multicolumn{14}{|c|}{ Jawaban Responden } \\
\hline \multirow{2}{*}{ Indikator } & \multicolumn{2}{|c|}{ STS (1) } & \multicolumn{2}{|c|}{ TS (2) } & \multicolumn{2}{|c|}{$\mathrm{N}(3)$} & \multicolumn{2}{|c|}{$\mathrm{S}(4)$} & \multicolumn{2}{|c|}{ SS (5) } & \multicolumn{2}{|c|}{ Total } & \multirow{2}{*}{ Modus } \\
\hline & $\mathrm{F}$ & $\%$ & $\mathrm{~F}$ & $\%$ & $\mathrm{~F}$ & $\%$ & $\mathrm{~F}$ & $\%$ & $\mathrm{~F}$ & $\%$ & $\mathrm{~F}$ & $\%$ & \\
\hline $\mathrm{Y}_{1}$ & 3 & 6 & 2 & 4 & 19 & 38 & 12 & 24 & 14 & 28 & 50 & 100 & 3 \\
\hline $\mathrm{Y}_{2}$ & 4 & 8 & 6 & 12 & 18 & 36 & 14 & 28 & 8 & 16 & 50 & 100 & 3 \\
\hline $\mathrm{Y}_{3}$ & 4 & 8 & 6 & 12 & 14 & 28 & 14 & 28 & 12 & 24 & 50 & 100 & 3 \\
\hline $\mathrm{Y}_{4}$ & 4 & 8 & 2 & 4 & 17 & 34 & 16 & 32 & 11 & 22 & 50 & 100 & 3 \\
\hline $\mathrm{Y}_{5}$ & 0 & 0 & 3 & 6 & 18 & 36 & 21 & 42 & 8 & 16 & 50 & 100 & 4 \\
\hline $\mathrm{Y}_{6}$ & 3 & 6 & 4 & 8 & 12 & 24 & 17 & 34 & 14 & 28 & 50 & 100 & 4 \\
\hline $\mathrm{Y}_{7}$ & 2 & 4 & 3 & 6 & 19 & 38 & 18 & 36 & 8 & 16 & 50 & 100 & 3 \\
\hline
\end{tabular}

Sumber: Data Primer, 2020

Di ketahui pada indikator $\left(\mathrm{Y}_{5}\right.$ dan $\mathrm{Y}_{6}$ ) menunjukan nilai modus 4 atau setuju, sedangkan indikator $\left(\mathrm{Y}_{\cdot 1}, \mathrm{Y}_{.2}, \mathrm{Y}_{\cdot 3}\right.$, Y.4, Y.7) menunjukan nilai modus 3 atau netral.

1) Pernyataan pada indikator $\left(Y_{1}\right)$ yaitu: keputusan pembelian minuman kopi di Pondok Kopi Umbul Sidomukti Sebanyak 19 responden (38\%) menjawab netral. Hal ini menyatakan bahwa responden tidak semuanya memang suka dengan minuman kopi walupun sudah minum kopi di Pondok Kopi Umbul Sidomukti.

2) Pernyataan pada indikator $\left(Y_{2}\right)$ yaitu: keputusan pembelian minuman kopi di Pondok Kopi Umbul Sidomukti karena konsumen merupakan pecinta minuman kopi. Sebanyak 18 responden $(36 \%)$ menjawab netral. Hal ini menyatakan bahwa tidak semua responden yang menjadi pecinta minuman kopi walaupun 
sudah meminum minuman kopi di pondok kopi umbul sidomukti.

3) Pernyataan pada indikator $\left(Y_{3}\right)$ yaitu: keputusan pembelian minuman kopi di Pondok Kopi Umbul Sidomukti karena sudah terbiasa mengkonsumsi minuman kopi. Sebanyak 14 responden (28\%) menyatakan setuju dan 14 responden (28\%) menyatakan netral. Hal ini menyatakan bahwa responden membeli minuman kopi di pondok kopi umbul sidomukti tidak semuanya terbiasa mengkonsumsi minuman kopi.

4) Pernyataan pada indikator $\left(Y_{4}\right)$ yaitu: keputusan pembelian minuman kopi di Pondok Kopi Umbul Sidomukti karena karena merasa puas dengan cita rasa yang disajikan. Sebanyak 17 responden (34\%) menyatakan netral. Hal ini menyatakan bahwa tidak semuanya responden membeli minuman kopi di Pondok Kopi Umbul Sidomukti merasa puas dengan cita rasa yang disajikan.

5) Pernyataan pada indikator $\left(Y_{5}\right)$ yaitu: keputusan pembelian minuman kopi di Pondok Kopi Umbul Sidomukti setiap berkunjung ke umbul sidomukti. Sebanyak 21 responden (42\%) menyatakan setuju. Hal ini menyatakan bahwa setiap responden berkunjung ke Umbul Sidomukti selalu membeli minuman kopi di Pondok Kopi Umbul Sidomukti.

6) Pernyataan pada indikator $\left(Y_{6}\right)$ yaitu: keputusan pembelian minuman kopi di Pondok Kopi Umbul Sidomukti karena sudah yakin mengambil keputusan yang tepat untuk membeli kopi di Pondok Kopi Umbul Sidomukti. Sebanyak 17 responden (34\%) menyatakan setuju. Hal ini menyatakan bahwa responden telah mengambil keputusan yang tepat untuk membeli minuman kopi di Pondok Kopi Umbul Sidomukti.

7) Pernyataan pada indikator $\left(Y_{7}\right)$ yaitu: keputusan pembelian minuman kopi di Pondok Kopi Umbul Sidomukti karena menyukai kualitas produk di Pondok Kopi Umbul Sidomukti yang baik. Sebanyak 19 responden (38\%) menyatakan netral. Hal ini menyatakan bahwa tidak semua responden membeli minuman kopi di Pondok Kopi Umbul Sidomukti karena menyukai kualitas produk yang baik. 
Tabel 7 Frekuensi Jawaban variabel kualitas produk

\begin{tabular}{|c|c|c|c|c|c|c|c|c|c|c|c|c|c|}
\hline \multicolumn{14}{|c|}{ Jawaban Responden } \\
\hline \multirow{2}{*}{ Indikator } & \multicolumn{2}{|c|}{ STS (1) } & \multicolumn{2}{|c|}{$\mathrm{TS}(2)$} & \multicolumn{2}{|c|}{$\mathrm{N}(3)$} & \multicolumn{2}{|c|}{ S (4) } & \multicolumn{2}{|c|}{ SS (5) } & \multicolumn{2}{|c|}{ Total } & \multirow{2}{*}{ Modus } \\
\hline & $\mathrm{F}$ & $\%$ & $\mathrm{~F}$ & $\%$ & $\mathrm{~F}$ & $\%$ & $\mathrm{~F}$ & $\%$ & $\mathrm{~F}$ & $\%$ & $\mathrm{~F}$ & $\%$ & \\
\hline $\mathrm{X}_{1.1}$ & 5 & 10 & 3 & 6 & 15 & 30 & 21 & 42 & 6 & 12 & 50 & 100 & 4 \\
\hline $\mathrm{X}_{1.2}$ & 4 & 8 & 4 & 8 & 18 & 36 & 18 & 36 & 6 & 12 & 50 & 100 & 3 \\
\hline $\mathrm{X}_{1.3}$ & 2 & 4 & 8 & 16 & 15 & 30 & 15 & 30 & 10 & 20 & 50 & 100 & 3 \\
\hline $\mathrm{X}_{1.4}$ & 4 & 8 & 9 & 18 & 16 & 32 & 13 & 26 & 8 & 16 & 50 & 100 & 3 \\
\hline $\mathrm{X}_{1.5}$ & 2 & 4 & 5 & 10 & 15 & 30 & 21 & 42 & 7 & 14 & 50 & 100 & 4 \\
\hline$X_{1.6}$ & 5 & 10 & 2 & 4 & 16 & 32 & 17 & 34 & 10 & 20 & 50 & 100 & 4 \\
\hline
\end{tabular}

Sumber: Data Primer, 2020

Di ketahui pada indikator $\left(\mathrm{X}_{1.1}, \mathrm{X}_{1.5}\right.$, $\mathrm{X}_{1.6}$ ) menunjukan nilai modus 4 atau setuju, sedangkan indikator $\left(\mathrm{X}_{1.2}, \mathrm{X}_{1.3}\right.$, $\mathrm{X}_{1.4}$ ) menunjukan nilai modus 3 atau netral.

1) Pernyataan pada indikator $\left(X_{.1 .1}\right)$ yaitu: kopi di Pondok Kopi Umbul Sidomukti produknya berkualitas karena memiliki cita rasa yang khas. Sebanyak 21 responden (42\%) menyatakan setuju, hal ini menyatakan bahwa responden setuju produk kopi di Pondok Kopi Umbul Sidomukti berkualitas karena memiliki cita rasa yang khas.

2) Pernyataan pada indikator $\left(X_{1.2}\right)$ yaitu: kopi di Pondok Kopi Umbul Sidomukti produknya berkualitas karena karena di sajikan dengan sangat unik. Sebanyak 18 responden (36\%) menyatakan setuju dan 18 responden (36\%) lagi menyatakan netral, hal ini menyatakan bahwa tidak semua responden setuju kualitas produk kopi di Pondok Kopi Umbul Sidomukti berkualitas karena disajikan dengan sangat unik.

3) Pernyataan pada indikator $\left(X_{1.3}\right)$ yaitu: kopi di Pondok Kopi Umbul Sidomukti produknya berkualitas karena karena kualitas produk sangat baik dan dikenal oleh masyarakat. Sebanyak 15 responden (30\%) menyatakan setuju dan 15 responden (30\%) lagi menyatakan netral, hal ini menyatakan bahwa tidak semua responden setuju kualitas produk kopi di Pondok Kopi Umbul Sidomukti berkualitas karena kualitas produk yang baik dan dikenal masyarakat.

4) Pernyataan pada indikator $\left(X_{1.4}\right)$ yaitu: kopi di Pondok Kopi Umbul Sidomukti produknya berkualitas karena karena di armanya yang kuat. Sebanyak 16 responden (32\%) menyatakan netral, hal ini menyatakan 
bahwa tidak semua responden menyatakan kualitas produk kopi di Pondok Kopi Umbul Sidomukti berkualitas karena aroma minuman kopi yang kuat.

5) Pernyataan pada indikator $\left(X_{1.5}\right)$ yaitu: kopi di Pondok Kopi Umbul Sidomukti produknya berkualitas karena memiliki banyak pilihan rasa. Sebanyak 21 responden (42\%) menyatakan setuju, hal ini menyatakan bahwa tidak semua responden setuju kualitas produk kopi di Pondok Kopi Umbul Sidomukti berkualitas karena memiliki banyak pilihan rasa.
6) Pernyataan pada indikator $\left(X_{1.6}\right)$ yaitu: kopi di Pondok Kopi Umbul Sidomukti produknya berkualitas karena sesuai dengan keinginan konsumen dengan rasa yang sesuai selera konsumen. Sebanyak 17 responden (36\%) menyatakan setuju, hal ini menyatakan bahwa semua responden setuju kualitas produk kopi di Pondok Kopi Umbul Sidomukti berkualitas karena sesuai dengan keinginan konsumen dengan rasa yang sesuai selera konsumen.

\section{Tabel 8 Frekuensi jawaban variabel kualitas pelayanan}

\begin{tabular}{|c|c|c|c|c|c|c|c|c|c|c|c|c|c|}
\hline \multicolumn{14}{|c|}{ Jawaban Responden } \\
\hline \multirow{2}{*}{ Indikator } & \multicolumn{2}{|c|}{ STS (1) } & \multicolumn{2}{|c|}{ TS (2) } & \multicolumn{2}{|c|}{$\mathrm{N}(3)$} & \multicolumn{2}{|c|}{ S (4) } & \multicolumn{2}{|c|}{ SS (5) } & \multicolumn{2}{|c|}{ Total } & \multirow{2}{*}{ Modus } \\
\hline & $\mathrm{F}$ & $\%$ & $\mathrm{~F}$ & $\%$ & $\mathrm{~F}$ & $\%$ & $\mathrm{~F}$ & $\%$ & $\mathrm{~F}$ & $\%$ & $\mathrm{~F}$ & $\%$ & \\
\hline $\mathrm{X}_{2.1}$ & 1 & 2 & 0 & 0 & 14 & 28 & 19 & 38 & 16 & 32 & 50 & 100 & 4 \\
\hline $\mathrm{X}_{2.2}$ & 0 & 0 & 2 & 4 & 14 & 28 & 24 & 48 & 10 & 20 & 50 & 100 & 4 \\
\hline $\mathrm{X}_{2.3}$ & 0 & 0 & 2 & 4 & 15 & 30 & 23 & 46 & 10 & 20 & 50 & 100 & 4 \\
\hline $\mathrm{X}_{2.4}$ & 0 & 0 & 5 & 10 & 19 & 38 & 15 & 30 & 11 & 22 & 50 & 100 & 3 \\
\hline $\mathrm{X}_{2.5}$ & 1 & 2 & 1 & 2 & 21 & 42 & 21 & 42 & 6 & 12 & 50 & 100 & 3 \\
\hline $\mathrm{X}_{2.6}$ & 0 & 0 & 4 & 8 & 16 & 32 & 17 & 34 & 13 & 26 & 50 & 100 & 4 \\
\hline
\end{tabular}

Sumber: Data Primer, 2020

Di ketahui pada indikator $\left(\mathrm{X}_{2.1}, \mathrm{X}_{2.2}\right.$, $\mathrm{X}_{2.3}, \mathrm{X}_{2.6}$ ) menunjukan nilai modus 4 atau setuju, sedangkan indikator $\left(\mathrm{X}_{2.4}, \mathrm{X}_{2.4},\right)$ menunjukan nilai modus 3 atau netral.

1) Pernyataan pada indikator $\left(X_{\cdot 2 \cdot 1}\right)$ yaitu: kualitas pelayanan di Pondok Kopi Umbul Sidomukti berkualitas karena karyawan yang melayani di pondok kopi umbul sidomukti berpakaian sangat rapi. Sebanyak 19 responden (38\%) menyatakan setuju, hal ini menyatakan bahwa responden setuju kualitas pelayanan di Pondok Kopi Umbul Sidomukti berkualitas karena karyawan yang melayani di pondok kopi umbul sidomukti berpakaian sangat rapi. 
2) Pernyataan pada indikator $\left(X_{\cdot 2 \cdot 2}\right)$ yaitu: kualitas pelayanan di Pondok Kopi Umbul Sidomukti berkualitas karena karyawan yang melayani di pondok kopi umbul sidomukti sangat sopan dan ramah. Sebanyak 24 responden $(48 \%)$ menyatakan setuju, hal ini menyatakan bahwa responden setuju kualitas pelayanan di Pondok Kopi Umbul Sidomukti berkualitas karena karyawan yang melayani di pondok kopi umbul sidomukti sangat sopan dan ramah.

3) Pernyataan pada indikator $\left(X_{\cdot 2 \cdot 3}\right)$ yaitu: kualitas pelayanan di Pondok Kopi Umbul Sidomukti berkualitas karena karyawan yang melayani di pondok kopi umbul sidomukti meletakan pesanan konsumen dengan hati-hati. Sebanyak 23 responden (46\%) menyatakan setuju, hal ini menyatakan bahwa responden setuju kualitas pelayanan di Pondok Kopi Umbul Sidomukti berkualitas karena karyawan yang melayani meletakan pesanan konsumen dengan sangat hatihati.

4) Pernyataan pada indikator (X.2.4) yaitu: kualitas pelayanan di Pondok Kopi Umbul Sidomukti berkualitas karena waktu menunggu pesanan tidak begitu lama. Sebanyak 19 responden
(38\%) menyatakan netral, hal ini menyatakan bahwa tidak semua responden menganggap kualitas pelayanan di Pondok Kopi Umbul Sidomukti berkualitas karena waktu menunggu pesanan tidak begitu lama.

5) Pernyataan pada indikator (X.2.5) yaitu: kualitas pelayanan di Pondok Kopi Umbul Sidomukti berkualitas karena sistem pemesanan yang baik dan tidak terlalu lama. Sebanyak 21 responden (42\%) menyatakan setuju dan 21 responden (42\%) menyatakan netral, hal ini menyatakan bahwa tidak semua responden setuju kualitas pelayanan di Pondok Kopi Umbul Sidomukti berkualitas karena sistem pemesanan yang baik dan tidak terlalu lama.

6) Pernyataan pada indikator (X.2.6) yaitu: kualitas pelayanan di Pondok Kopi Umbul Sidomukti berkualitas karena waktu menunggu pesanan bisa mendengarkan musik yang di putarkan di pondok kopi. Sebanyak 17 responden (34\%) menyatakan setuju, hal ini menyatakan bahwa responden menganggap kualitas pelayanan di Pondok Kopi Umbul Sidomukti berkualitas karena waktu menunggu pesanan konsumen bisa mendengarkan musik yang diputarkan. 
Tabel 9 Frekuensi Jawaban Variabel Lokasi

\begin{tabular}{|c|c|c|c|c|c|c|c|c|c|c|c|c|c|}
\hline \multicolumn{14}{|c|}{ Jawaban Responden } \\
\hline \multirow{2}{*}{ Indikator } & \multicolumn{2}{|c|}{ STS (1) } & \multicolumn{2}{|c|}{$\mathrm{TS}(2)$} & \multicolumn{2}{|c|}{$\mathrm{N}(3)$} & \multicolumn{2}{|c|}{ S (4) } & \multicolumn{2}{|c|}{ SS (5) } & \multicolumn{2}{|c|}{ Total } & \multirow[t]{2}{*}{ Modus } \\
\hline & $\mathrm{F}$ & $\%$ & $\mathrm{~F}$ & $\%$ & $\mathrm{~F}$ & $\%$ & $\mathrm{~F}$ & $\%$ & $\mathrm{~F}$ & $\%$ & $\mathrm{~F}$ & $\%$ & \\
\hline $\mathrm{X}_{3.1}$ & 4 & 8 & 3 & 6 & 23 & 46 & 11 & 22 & 9 & 18 & 50 & 100 & 3 \\
\hline $\mathrm{X}_{3.2}$ & 4 & 8 & 1 & 2 & 30 & 60 & 9 & 18 & 6 & 12 & 50 & 100 & 3 \\
\hline $\mathrm{X}_{3.3}$ & 3 & 6 & 4 & 8 & 22 & 44 & 17 & 34 & 4 & 8 & 50 & 100 & 3 \\
\hline $\mathrm{X}_{3.4}$ & 3 & 6 & 4 & 8 & 19 & 38 & 19 & 38 & 5 & 10 & 50 & 100 & 3 \\
\hline
\end{tabular}

Sumber: Data Primer, 2020

Diketahui pada indikator $\left(\mathrm{X}_{3.1}, \mathrm{X}_{3.2}\right.$, $\left.\mathrm{X}_{3.3}, \mathrm{X}_{3.4}\right)$ menunjukan nilai modus 3 netral.

1) Pernyataan pada indikator $\left(X_{3 \cdot 1}\right)$ yaitu: lokasi ke Pondok Kopi Umbul Sidomukti mudah dijangkau. Sebanyak 23 responden $(46 \%)$ menyatakan netral, hal ini menyatakan bahwa tidak semua responden setuju lokasi pondok Pondok Kopi Umbul Sidomukti mudah di jangkau namun ada beberapa responden yang menyatakan sangat tidak setuju dan tidak setuju hal ini berarti beberapa orang ini tidak setuju dengan kemudahan menjangkau lokasi dikarenakan jalan yang tidka terlalu mulus.

2) Pernyataan pada indikator $\left(X_{3 \cdot 2}\right)$ yaitu: lokasi ke Pondok Kopi Umbul Sidomukti memiliki tempat parkir yang luas nyaman dan aman. Sebanyak 30 responden (60\%) menyatakan netral, hal ini menyatakan bahwa lebih dari setengah responden tidak semua setuju bahwa lokasi pondok Pondok Kopi Umbul Sidomukti memiliki tempat parkir yang luas aman dan nyaman.

3) Pernyataan pada indikator $\left(X_{3 \cdot 3}\right)$ yaitu: lokasi ke Pondok Kopi Umbul Sidomukti dekat dengan fasilitas umum. Sebanyak 22 responden (44\%) menyatakan netral, hal ini menyatakan bahwa tidak semua responden setuju lokasi pondok Pondok Kopi Umbul Sidomukti dekat dengan fasilitas umum.

4) Pernyataan pada indikator $\left(X_{3 \cdot 4}\right)$ yaitu: lokasi ke Pondok Kopi Umbul Sidomukti jauh dari kepadatan dan kemacetan lalu lintas. Sebanyak 19 responden $(38 \%)$ menyatakan setuju dan 19 responden (38\%) menyatakan netral, hal ini menyatakan bahwa tidak semua responden setuju lokasi pondok Pondok Kopi Umbul Sidomukti jauh dari kepadatan dan kemacetan lalu lintas. 
Tabel 10 Frekuensi Jawaban Variabel Lingkungan

\begin{tabular}{|c|c|c|c|c|c|c|c|c|c|c|c|c|c|}
\hline \multicolumn{14}{|c|}{ Jawaban Responden } \\
\hline \multirow{2}{*}{ Indikator } & \multicolumn{2}{|c|}{ STS (1) } & \multicolumn{2}{|c|}{ TS (2) } & \multicolumn{2}{|c|}{$\mathrm{N}(3)$} & \multicolumn{2}{|c|}{ S (4) } & \multicolumn{2}{|c|}{ SS (5) } & \multicolumn{2}{|c|}{ Total } & \multirow[t]{2}{*}{ Modus } \\
\hline & $\mathrm{F}$ & $\%$ & $\mathrm{~F}$ & $\%$ & $\mathrm{~F}$ & $\%$ & $\mathrm{~F}$ & $\%$ & $\mathrm{~F}$ & $\%$ & $\mathrm{~F}$ & $\%$ & \\
\hline $\mathrm{X}_{4.1}$ & 2 & 4 & 6 & 12 & 15 & 30 & 20 & 40 & 7 & 14 & 50 & 100 & 4 \\
\hline $\mathrm{X}_{4.2}$ & 3 & 6 & 2 & 4 & 21 & 42 & 18 & 36 & 6 & 12 & 50 & 100 & 3 \\
\hline $\mathrm{X}_{4.3}$ & 0 & 0 & 5 & 10 & 23 & 46 & 19 & 38 & 3 & 6 & 50 & 100 & 3 \\
\hline $\mathrm{X}_{4.4}$ & 2 & 4 & 1 & 2 & 11 & 22 & 23 & 46 & 13 & 26 & 50 & 100 & 4 \\
\hline
\end{tabular}

Sumber: Data Primer, 2020

Di ketahui pada indikator $\left(\mathrm{X}_{4.1}, \mathrm{X}_{4.4}\right)$ menunjukan nilai modus 4 setuju dan indikator $\left(\mathrm{X}_{4.2}, \mathrm{X}_{4.3}\right)$ menunjukan nilai modus 3 netral.

1) Pernyataan pada indikator $\left(X_{4 \cdot 1}\right)$ yaitu: karena situasi tempat yang nyaman konsumen membeli minuman kopi. Sebanyak 20 responden $(40 \%)$ menyatakan setuju, hal ini menyatakan bahwa responden setuju lingkungan pondok Pondok Kopi Umbul Sidomukti memiliki situasi tempat yang nyaman.

2) Pernyataan pada indikator $\left(X_{4 \cdot 2}\right)$ yaitu: karena tempat yang bisa bersantai lebih lama konsumen membeli minuman kopi di Pondok Kopi Umbul Sidomukti. Sebanyak 21 responden (42\%) menyatakan netral, hal ini menyatakan bahwa tidak semua responden setuju lingkungan pondok
Pondok Kopi Umbul Sidomukti bisa membuat bersantai lebih lama.

3) Pernyataan pada indikator $\left(X_{4 \cdot 3}\right)$ yaitu: karen konsumen diajak oleh keluarga untuk membeli minuman kopi di Pondok Kopi Umbul Sidomukti, sebanyak 23 responden (46\%) menyatakan netral, hal ini menyatakan bahwa tidak semua responden setuju bahwa membeli minuman kopi karena di ajak keluarga.

4) Pernyataan pada indikator $\left(X_{4.4}\right)$ yaitu: lingkungan Pondok Kopi Umbul Sidomukti. Konsumen yang membeli minuman kopi karena ikut teman yang membeli minuman kopi di Pondok Kopi Umbul Sidomukti. Sebanyak 23 responden $(46 \%)$ menyatakan setuju, hal ini menyatakan bahwa responden setuju karena ikut teman yang membeli minuman di Pondok Kopi Umbul Sidomukti. 


\section{Hasil Analisis Hubungan antara Kualitas Produk $\left(\mathbf{X}_{1}\right)$ Kualitas Pelayanan $\left(\mathbf{X}_{2}\right)$} Lokasi $\left(\mathrm{X}_{3}\right)$ dan Lingkungan $\left(\mathrm{X}_{4}\right)$ dengan Keputusan Pembelian (Y)

Tabel 11. Hubungan antara faktor kualitas produk (X1), kualitas pelayanan (X2), Lokasi (X3) dan lingkungan (X4) dengan keputusan pembelian (Y) di Pondok Kopi Umbul Sidomukti

\begin{tabular}{lcccccc}
\hline \multicolumn{1}{c}{ Variabel } & $\left(\boldsymbol{r}_{\boldsymbol{s}}\right)$ & $\mathbf{\alpha ( 0 , 0 5 )}$ & $\mathbf{t}$ hitung & $\mathbf{t}$ tabel & $\begin{array}{c}\text { Hasil uji } \\
\text { Statistik }\end{array}$ & $\begin{array}{c}\text { Tingkat } \\
\text { keeratan } \\
\text { hubungan }\end{array}$ \\
\hline Kualitas Produk $\left(\mathrm{X}_{1}\right)$ & $0.664^{*}$ & 0.000 & 5.98 & 2.014 & Signifikan & Kuat \\
Kualitas Pelayanan $\left(\mathrm{X}_{2}\right)$ & $0.462^{*}$ & 0.001 & 3.61 & 2.014 & Signifikan & Sedang \\
Lokasi $\left(\mathrm{X}_{3}\right)$ & $0.484^{*}$ & 0.000 & 3.83 & 2.014 & Signifikan & Sedang \\
Lingkungan $\left(\mathrm{X}_{4}\right)$ & $0.584^{*}$ & 0.000 & 4.98 & 2.014 & Signifikan & Sedang \\
\hline
\end{tabular}

Sumber: Data Primer, 2020

Dapat dilihat pada tabel 11 menunjukkan hasil dari analisis korelasi Rank Spearman bahwa variabel kualitas produk, kualitas pelayanan, lokasi dan lingkungan yang digunakan dalam penelitian ini terdapat hubungan yang signifikan terhadap keputusan pembelian dengan nilai eror dibawah 0,01.

\section{Hubungan antara Kualitas Produk dengan Keputusan Pembelian}

Hasil analisis pada tabel 11 dapat dilihat bahwa nilai koefisien korelasi antara kualitas produk dengan keputusan pembelian di Pondok Kopi Umbul Sidomukti sebesar 0,664 dengan tanda positif dan signifikan pada taraf kepercayaan 99\%. Hal ini menunjukkan bahwa kualitas produk memiliki arah hubungan yang positif serta tingkat hubungan yang kuat dengan keputusan pembelian di Pondok Kopi Umbul
Sidomukti, dimana koefisien kualitas produk berada pada interval 0.60-0.79 sesuai dengan interpretasi kuatnya hubungan korelasi menurut Sugiyono (2014), Hal ini juga dapat dilihat pada hasil uji $t$ yaitu nilai $t_{\text {hitung }} 5.98>2.014$ $t_{\text {tabel }}$ menunjukkan bahwa variabel kualitas produk berkorelasi signifikan terhadap keputusan pembelian, artinya semakin kualitas produk ditingkatkan maka semakin tinggi keputusan pembelian minuman kopi.

Kualitas produk memiliki hubungan yang nyata memiliki arti bahwa semakin kualitas produk ditingkatkan maka semakin besar pula keputusan pembelian dan sebaliknya. Sudah sesuai dengan wujud tampilan luar atau penyajian produk kopi menarik serta kualitas yang baik menurut, (Lupiyoadi, 2011). 
Berdasarkan frekuensi jawaban responden diketahui kualitas produk yang diterima oleh responden termasuk ketegori kuat, responden melakukan pembelian minuman kopi karena memang memiliki cita rasa yang khas dengan penyajian yang menarik dan unik. Responden juga tertarik pada kopi yang memiliki aroma yang kuat serta banyaknya pilihan rasa yang ditawarkan serta produk kopi yang disajikan sesuai dengan keinginan konsumen dengan rasa sesuai selera konsumen selain itu karena produknya sangat baik dan sudah dikenal oleh masyarakat. Kualitas produk yang diberikan oleh tempat pondok kopi akan membuat responden lebih cepat dalam memutuskan membeli minuman kopi.

\section{Hubungan antara Kualitas Pelayanan dengan Keputusan Pembelian}

Hasil dari tabel 11, dapat dilihat bahwa nilai koefisien korelasi antara kualitas pelayanan dengan keputusan pembelian di Pondok Kopi Umbul Sidomukti sebesar 0.462 dengan tanda positif dan signifikan pada taraf kepercayaan 99\%. Hal ini menunjukkan bahwa kualitas pelayanan memiliki hubungan yang positif serta tingkat hubungan yang kuat dengan keputusan pembelian di Pondok Kopi Umbul Sidomukti, yang artinya semakin tinggi kualitas pelayanan maka semakin tinggi pula keputusan konsumen untuk membeli minuman kopi. Selain itu, kualitas pelayanan memiliki keeratan hubungan sedang dengan keputusan pembelian dimana koefisien kualitas pelayanan berada pada interval 0,40-0,59 sesuai dengan interpretasi kuatnya hubungan korelasi menurut Sugiyono (2014). Hal ini juga dapat dilihat pada hasil uji t yaitu nilai $t_{\text {hitung }} 3,61>2,014 t_{\text {tabel }}$ menunjukkan bahwa keputusan pembelian dengan variabel kualitas pelayanan berkorelasi signifikan terhadap keputusan pembelian, artinya hubungan yang nyata antara kualitas pelayanan dengan keputusan pembelian susu memiliki arti bahwa kualitas pelayanan semakin ditingkatkan maka semakin besar pula keputusan pembelian dan sebaliknya. Hal ini juga sama dalam penelitian (Daulay, 2017), apabila kualitas pelayanan yang diterima atau dirasakan sesuai dengan yang diharapkan maka kualitas pelayanan dipersepsikan baik dan memuaskan. Jika kualitas pelayanan yang diterima melampaui harapan konsumen maka kualitas pelayanan dipersepsikan sebagai kualitas yang ideal dan memiliki pengaruh yang signifikan terhadap keputusan pembelian artinya jika konsumen merasa 
puas dengan pelayanan maka konsumen akan membeli.

Berdasarkan frekuensi jawaban responden diketahui kualitas pelayanan yang diterima oleh responden termasuk ketegori sedang, responden melakukan pembelian minuman kopi karena memang pelayanan di Pondok Kopi Umbul Sidomukti sangat ramah dan sopan juga berpakaian rapi selain itu juga Sistem pemesanan yang baik dan waktu menunggu pesanan yang tidak terlalu lama, dan pada saat mengantarkan pesanan dan meletakan pesanan dengan sangat hati-hati, konsumen merasa nyaman karena bisa mendengarkan musik yang di putarkan sambal menunggu pesanan. Pelayanan yang memuaskan di atas akan membuat responden cepat dalam memutuskan pembelian minuman kopi dan hal tersebut membuat pengunjung untuk melakukan kunjungan pembelian lagi.

\section{Hubungan antara Lokasi dengan Keputusan Pembelian}

Hasil dari analisis pada tabel 11 dapat dilihat bahwa nilai koefisien korelasi antara lokasi dengan keputusan pembelian di Pondok Kopi Umbul Sidomukti sebesar 0.484 dengan tanda positif dan signifikan pada taraf kepercayaan 99\%. Hal ini menunjukkan bahwa lokasi memiliki hubungan yang positif dan signifikan serta tingkat hubungan yang sedang dengan keputusan pembelian di Pondok Kopi Umbul Sidomukti, dimana koefisien lokasi berada pada interval 0,40 - 0,59 sesuai dengan interpretasi Kuatnya hubungan korelasi menurut Sugiyono (2014),Hal ini dapat dilihat dari uji t yaitu $t_{\text {hitung }} 3,83>2,014 t_{\text {tabel }}$ menunjukkan bahwa variabel lokasi berkorelasi signifikan terhadap keputusan pembelian, artinya Hubungan lokasi dengan keputusan pembelian minuman kopi yang nyata memiliki arti bahwa semakin terjangkau lokasi penjualan semakin besar juga keputusan pembelian susu segar dan sebaliknya semakin jauh lokasi penjualan maka semakin berkurangnya jumlah pembelian. Selain itu penentu lainya adalah akses atau lalu lintas salah satunya ada orang yang berlalu lalang berpeluang terjadinya keputusan pembelian yang spontan. Lokasi merupakan faktor yang penting pada lokasi yang tepat sebuah gerai akan lebih sukses dibanding gerai lainnya dan keputusan pembelian (Tjiptono and Chandra, 2011).

Berdasarkan frekuensi jawaban responden diketahui lokasi memiliki hubungan terhadap keputusan pembelian karena responden melakukan pembelian minuman kopi ketempat yang lumaian 
mudah untuk dijangkau, tempat parkir yang luas, nyaman serta aman. Selain itu, responden juga memilih tempat penjualan yang dekat fasilitas umum yang di sediakan ada hotel dan penginapan serta tempat rekreasi. Disamping itu, letak lokasi pondok kopi yang jauh dari kepadatan dan kemacetan lalu lintas membuat konsumen nyaman untuk berdiskusi lama serta tidak terganggu dengan suara dan polusi kendaraan.

\section{Hubungan antara Lingkungan dengan Keputusan Pembelian}

Hasil dari tabel 11, dapat dilihat bahwa nilai koefisien korelasi antara lingkungan dengan keputusan pembelian di Pondok Kopi Umbul Sidomukti sebesar 0.548 dengan tanda positif dan signifikan pada taraf kepercayaan 99\%. Hal ini menunjukkan bahwa lingkungan memiliki hubungan yang positif serta tingkat hubungan yang sedang dengan keputusan pembelian di Pondok Kopi Umbul Sidomukti, dimana koefisien lingkungan berada pada interval 0,40-0,59 sesuai dengan interpretasi kuatnya hubungan korelasi menurut Sugiyono (2014), Hal ini juga dapat dilihat pada hasil uji t yaitu nilai thitung 4,98>2,014 $\mathrm{t}_{\text {tabel }}$ menunjukkan variabel lingkungan berkorelasi signifikan terhadap keputusan pembelian, artinya Hubungan yang nyata antara lingkungan dengan keputusan pembelian memiliki arti bahwa lingkungan keluarga dan lingkungan sosial mempengaruhi konsumen untuk membeli minuman kopi, menurut Sunanto (2015), bahwa adanya hubungan antara faktor lingkungan konsumen dengan keputusan pembelian. Artinya jika hubungan lingkungan konsumen ditingkatkan maka meningkat pula keputusan pembelian..

Berdasarkan frekuensi jawaban responden diketahui bahwa lingkungan memiliki hubungan sedang terhadap keputusan pembelian, lingkungan tempat yang nyaman membuat konsumen ingin membeli minuman kopi sambil menikmati suasana alam dan pemandangan serta bisa bersantai lebih lama ngobrol dengan teman atau keluarga. Selain faktor yang di atas keluarga juga berperan penting untuk membuat konsumen memutuskan untuk membeli minuman kopi menurut Buchari (2000), keluarga adalah lingkungan yang terdekat yang berpengaruh terhadap nilainilai dan prilaku seseorang dalam mengkonsumsi suatu produk. karena ketika dibawa oleh keluarga berlibur dengan cuaca dingin di Umbul Sidomukti membuat konsumen membeli kopi yang cocok untuk cuaca dingin, serta tidak hanya keluarga yang berperan melainkan teman juga ikut berperan untuk membuat 
konsumen membeli minuman kopi, ketika seorang teman memesan kopi kemungkinan konsumen juga lebih cenderung ingin minum kopi dengan situasi yang mendukung(Engel dkk, 2001).

\section{KESIMPULAN DAN SARAN}

\section{Kesimpulan}

Berdasarkan hasil analisis dan pembahasan penelitian tentang hubungan faktor kualitas produk, kualitas pelayanan, lokasi, dan lingkungan dengan keputusan pembelian minuman kopi di Pondok Kopi Umbul Sidomukti, dapat dilihat nilai koefisien korelasi $\left(r_{S}\right)$ dengan tingkat keeratan hubungan sebagai berikut:

1. Kualitas produk $\left(\mathrm{X}_{1}\right)$ memiliki hubungan yang signifikan dan positif, serta memiliki tingkat hubungan yang kuat dengan minuman kopi (Y).

2. Kualitas pelayanan $\left(X_{2}\right)$ memiliki hubungan yang signifikan dan positif, serta tingkat hubungan yang sedang keputusan pembelian minuman kopi (Y).

3. Lokasi $\left(\mathrm{X}_{3}\right)$ memiliki hubungan yang signifikan dan positif, serta memiliki tingkat hubungan sedang dengan keputusan pembelian minuman kopi (Y).

4. Lingkungan $\left(\mathrm{X}_{4}\right)$ memiliki hubungan yang signifikan dan positif, serta memiliki tingkat hubungan sedang dengan keputusan pembelian minuman kopi (Y).

\section{Saran}

Berdasarkan pembahasan dan kesimpulan diatas, maka dapat direkomendasikan saran penelitian sebagai berikut:

1. Pihak pondok kopi umbul sidomukti diharapkan lebih memperhatikan akses jalan yang kurang baik untuk dilakukan perbaikan serta tetap menjaga lingkungan pondok kopi tetap nyaman dan aman agar tetap menjadi daya tarik bagi konsumen untuk membeli minuman kopi di Pondok Kopi Umbul Sidomukti. Selain itu tetap mempertahan memberikan pelayanan yang berkualitas serta produk yang berkualitas.

2. Bagi peneliti selanjutnya, diharapkan dapat melakukan penelitian ini dengan meneliti faktor lain yang dapat mempengaruhi keputusan pembelian, misalnya faktor budaya dan variabel harga.

3. Untuk pihak Pondok Kopi kiranya bisa memberikan izin supaya mahasiswa dari fakultas pertanian dan bisnis uksw untuk melakukan penelitian di Pondok Kopi lagi.

\section{DAFTAR PUSTAKA}

Buchari, A. (2000) Manajemen Pemasaran dan Pemasaran Jasa. Cetakan Ke. Bandung: Alfabeta.

Daulay, N. (2017) Pengaruh Kualitas Pelayanan dan Kualitas Produk Terhadap Keputusan Pembelian. 
Engel, J. F., Blackwell, R. D. and Miniard, P. W. (2001) 'Perilaku Konsumen, Jilid 2', Jakarta: Binarupa Aksara.

Kementerian Pertanian (2016) 'Outlook Kopi Komoditas Pertanian Subsektor Perkebunan', Pusat Data Dan Sistem Informasi Pertanian Sekretariat Jenderal.

Kotler, P. \& Armstrong, G. (2008) 'Prinsip-Prinsip Pemasaran. Edisi 12. Jilid 1.', Manajemen Pemasaran.

Kotler dan Amstrong (2008) PrinsipPrinsip Pemasaran Jilid I, Erlangga.

Kurniawan, A. and Ridlo, M. R. (2017) 'Perilaku Konsumtif Remaja Penikmat Warung Kopi', Jurnal Sosiologi DILEMA.

Lupiyoadi (2011) Manajemen Pemasaran Jasa Teori dan Praktik, Salemba Empat. doi: 10.1002/cb.84.

Marhaenanto, B., Soedibyo, D. W. and Farid, M. (2015) 'Penentuan lama SangraKopi Terhadap Variasi Derajat Sangrai Menggunakan Model Warna Rgb Pada Pengolahan Citra Digital (Digital Image Processing)', Jurnal Agroteknologi.

Pertanian, P. D. dan S. I. (2019) 'Outlook 2018 Komoditas Pertanian Subsektor Perkebunan Kopi', Journal of Chemical Information and Modeling. doi: 10.1017/CBO9781107415324.004.

Ria, R. and Yuliawati, Y. (2018) 'Hubungan Harga, Lokasi, Kualitas Produk, Kualitas Pelayanan Dan Lingkungan Dengan Keputusan Pembelian Susu Segar Di Kecamatan Sidorejo, Salatiga, Jawa Tengah', Jurnal Sosial Ekonomi Pertanian. doi: 10.20956/jsep.v14i3.4917.

Sugiyono (2014) 'Teknik Pengumpulan Data', Metode Penelitian Kuantitatif, Kualitatif dan R\&D. doi: $10.3354 / \mathrm{dao} 02420$.

Sugiyono, P. D. (2014) 'Populasi dan sampel', Metode Penelitian Kuantitatif, Kualitatif dan R\&D.

Sunanto (2015) 'Analisis Pengaruh Faktor Individu, Lingkungan Konsumen, Dan Strategi Pemasaran Terhadap Keputusan Pembelian Pada Apotik Sunfarma Tangerang Selatan', Jurnal Ilmiah Prodi Manajemen Universitas Pamulang, 3, No.1, pp. 2-26.

Tjiptono, F. and Chandra, G. (2011) 'Service, Quality \& Satisfaction', in Edisi $4 . \quad$ doi: 10.3389/fgene.2015.00293. 